\title{
INFLUENCE OF FUNGICIDE SEED TREATMENT ON SOYBEAN NODULATION AND GRAIN YIELD ${ }^{(1)}$
}

\author{
Jerri Édson Zilli( ${ }^{(2)}$, Karen Gonçalves Ribeiro ${ }^{(3)}$, Rubens José \\ Campo $^{(4)}$ \& Mariangela Hungria ${ }^{(4)}$
}

\begin{abstract}
SUMMARY
Biological $\mathrm{N}_{2}$ fixation is a major factor contributing to the increased competitiveness of Brazilian soybeans on the international market. However, the contribution of this process may be limited by adverse conditions to symbiotic bacteria, such as fungicide seed treatments. This study aimed to evaluate the effects of the fungicides carbendazim + thiram and carboxin + thiram on soybean nodulation, plant growth and grain yield. Two field experiments were carried out in the Cerrado region of the State of Roraima, in a soil with a low organic matter content and no soybean bradyrhizobia. In 2005 , seeds were treated with fungicide carbendazim + thiram and commercial inoculants containing the Bradyrhizobium elkanii strains SEMIA 5019 and SEMIA 587 and B. japonicum strains SEMIA 5079 and SEMIA 5080. In 2006, soybean seeds were treated with the fungicides carbendazim + thiram or carboxin + thiram and inoculated separately with each one of the four strains. The plants were evaluated for number of nodules and dry weight, shoot dry weight and total $\mathrm{N}$ accumulated in shoots 35 days after plant emergence, while grain yield and $\mathbf{N}$ grain content were determined at harvest. Both fungicides reduced soybean nodulation, especially in the presence of $B$. elkanii strains. The fungicide carbendazim + thiram reduced nodulation by about $50 \%$ and grain yield by more than $20 \%$ (about $700 \mathrm{~kg} \mathrm{ha}^{-1}$ ), in the treatment inoculated with of strain SEMIA 587.
\end{abstract}

Index terms: Glycine max, carbendazim, thiram, carboxin, BNF, Cerrado.

\footnotetext{
(1) Received on November, 2008 and accepted on April, 2009.

(2) Embrapa Roraima - BR 174, km 08, Distrito Industrial, P.O. Box 133, CEP 69307-970 Boa Vista (RR). E-mail: zilli@cpafrr.embrapa.br

(3) Faculdades Cathedral - Av. Ville Roy 2003, Caçari, CEP 69307-053 Boa Vista (RR). E-mail: karenkgr@gmail.com

(4) Embrapa Soja. P.O. Box 231. Rod. Carlos João Strass, CEP 86001-970 Londrina (PR) E-mails: rjcampo@cnpso.embrapa.br; hungria@cnpso.embrapa.br
} 


\title{
RESUMO: INFLUÊNCIA DOTRATAMENTODE SEMENTES COMFUNGICIDAS NA NODULAÇÃO E RENDIMENTO DE GRÃOS DA SOJA
}

\begin{abstract}
A fixação biológica de $\mathrm{N}_{2}$ representa um dos principais fatores que aumentam a competitividade da soja no mercado internacional. Entretanto, a resposta desse processo pode ser limitada por condições adversas à bactéria, como o tratamento de sementes com fungicidas. O objetivo deste estudo foi avaliar o efeito de fungicidas à base de carbendazim + tiram e carboxin + tiram sobre a nodulação, o desenvolvimento das plantas e o rendimento de grãos da cultura da soja. Dois experimentos foram realizados no Cerrado do Estado de Roraima, em solo com baixo teor de matéria orgânica e desprovido de bactérias nodulantes de soja. Em 2005, as sementes de soja foram tratadas com fungicida à base de carbendazim + tiram e inoculação com produtos comerciais contendo as estirpes de Bradyrhizobium elkanii SEMIA 5019 e SEMIA 587 e B. japonicum SEMIA 5079 e SEMIA 5080. Em 2006, as sementes foram tratadas com fungicidas à base de carbendazim+tiram ou carboxin + tiram e inoculação individual com cada uma das quatro estirpes. Aos 35 dias após a emergência das plantas de soja, foram realizadas avaliações da nodulação, matéria seca e $N$-total da parte aérea e, na colheita, foram avaliados a produtividade e o $N$ total acumulado nos grãos. Ambos os fungicidas reduziram a nodulação das plantas de soja, sobretudo para as estirpes de B. elkanii. O fungicida à base de carbendazim + tiram reduziu significativamente (cerca de $50 \%$ ) a nodulação e em mais de $20 \%$ (cerca de $700 \mathrm{~kg} \mathrm{ha}^{-1}$ ), o rendimento de grãos no tratamento inoculado com a estirpe SEMIA 587.
\end{abstract}

Termos de indexação: Glycine max, carbendazim, tiram, carboxin, FBN, Cerrado.

\section{INTRODUCTION}

Soybean is one of the main products of Brazilian agricultural with a trade balance of more than 11 billion dollars per year 2007 (CONAB, 2008). One of the main factors that has made this commodity competitive on the international market is the biological $\mathrm{N}_{2}$ fixation (BNF), which represents a contribution of more than US $\$ 4$ billion, which in 2007 was equivalent to more than $30 \%$ of the trade balance of the soybean complex. In recent decades, the crop has expanded to diverse areas of the country and has reached the Cerrado region of Roraima, where around 10 thousand hectares are currently cultivated with soybean.

The adaptability of the crop to the most diverse soil-climatic conditions is mostly due to BNF, which substitutes mineral $\mathrm{N}$ fertilization completely, resulting in a significant reduction of the production costs (Hungria et al., 2007). In fact, in areas such as the Cerrado of Roraima, where soil organic matter content is naturally less than $10 \mathrm{~g} \mathrm{~kg}^{-1}$, the utilization of BNF by seed inoculation with selected Bradyrhizobium strains has become indispensable for the economic viability of soybean.

The response of BNF is related to various soilclimatic factors that influence the plant and the bacteria itself, especially in areas where soybean is planted for the first time and where effective BNF bacteria for the crop are absent (Hungria et al., 2000; Graham, 2008). Another problem that has also attracted attention is the fungicide seed treatment, posing the risk of limiting plant nodulation, with consequent grain yield reduction (Andrés et al., 1998; Campo \& Hungria, 2000).

Part of the fungicides available for soybean seed treatment in Brazil are composed of mixtures of the systemic active ingredients carbendazim and carboxin with the contact fungicide thiram. These fungicides are recommended for soybean seed treatment with a view to reducing pathogen transmission via seed, e.g., of Cercospora kikuchii, Cercospora sojina, Fusarium semitectum, Phomopsis spp., as well as infestation by soil fungi such as Rhizoctonia solani, Pythium spp., Fusarium spp. and Aspergillus spp.; particularly under drought, which delays plant emergence, these pathogens may reduce the crop stand (Embrapa, 2008).

Studies have shown that these fungicides may be harmful to the strains of Bradyrhizobium used in commercial inoculants for the soybean crop (Campo $\&$ Hungria, 2000). Nevertheless, little is known about these effects in field conditions, especially in soil lacking soybean-nodulating bacteria and with a very low organic matter content.

This study aimed at evaluating the effect of carbendazin + thiram and carboxin + thiram fungicides on nodulation, development of soybean plants and grain yield under field conditions in the Cerrado of Roraima.

\section{MATERIAL AND METHODS}

In the growing seasons of 2005 and 2006, two 
experiments were performed in a native Cerrado area of the experimental area Água Boa of Embrapa Roraima, in the county of Boa Vista - RR (W $60^{\circ} 39^{\prime} 54^{\prime \prime}$ and $\mathrm{N} 02^{\circ} 15^{\prime} 00$ "). The experimental area was prepared in 2004, with the application of $1.5 \mathrm{t} \mathrm{ha}^{-1}$ of dolomitic lime (ECC $80 \%$ ), $100 \mathrm{~kg} \mathrm{ha}^{-1}$ $\mathrm{P}_{2} \mathrm{O}_{5}$ in the form of simple superphosphate and $50 \mathrm{~kg} \mathrm{ha}^{-1}$ of FTE BR-12. After soil preparation, millet was sown, which was desiccated with a glyphosatebased herbicide, according to the technical recommendations for the product. The area of the first and second experiment differed only in that soybean was sown in 2005 and millet in 2006 in the first, and millet in both years in the second.

Soil analysis prior to the experiments in 2005 at a depth of $0-20 \mathrm{~cm}$ exhibited the following characteristics: $\mathrm{pH}\left(\mathrm{CaCl}_{2}\right) 5.2 ; \mathrm{Al} 0.00 \mathrm{cmol}_{\mathrm{c}} \mathrm{dm}^{-3} ; \mathrm{K}$ $0.05 \mathrm{cmol}_{\mathrm{c}} \mathrm{dm}^{-3} ; \mathrm{Ca} 1.10 \mathrm{cmol}_{\mathrm{c}} \mathrm{dm}^{-3} ; \mathrm{Mg} 0.30 \mathrm{cmol}_{\mathrm{c}} \mathrm{dm}^{-3}$; organic matter $10.11 \mathrm{~g} \mathrm{dm}^{-3} ; \mathrm{P} 31 \mathrm{mg} \mathrm{dm}^{-3} ; 870 \mathrm{~g} \mathrm{~kg}^{-1}$ of sand, $120 \mathrm{~g} \mathrm{~kg}^{-1}$ of clay and $10 \mathrm{~g} \mathrm{~kg}^{-1}$ of silt; and soybean-nodulating rhizobium cells $=10$ colony forming units (CFU) $\mathrm{g}^{-1}$ of soil.

As base fertilization, $90 \mathrm{~kg} \mathrm{ha}^{-1}$ of $\mathrm{P}_{2} \mathrm{O}_{5}$ in the simple superphosphate form and $100 \mathrm{~kg} \mathrm{ha}^{-1}$ of $\mathrm{K}_{2} \mathrm{O}$ in the potassium chloride form (50\% at planting and $50 \% 35$ days after plant emergence - DAE) were used. At thirty-five DAE, 2,5 $\mathrm{g} \mathrm{ha}^{-1}$ Co was applied to the leaves in the form of cobalt chloride and $20,0 \mathrm{~g} \mathrm{ha}^{-1}$ Mo in the form of sodium molybdate. The crop management in the experiment was according to the recommendations for the region (Embrapa Roraima, 2007).

Both experiments were conducted in randomized blocks design with six replications, in $5 \times 4 \mathrm{~m}$ plots. Soybean seeds (BRS Tracajá cultivar) were broadcast by hand with a spacing of $0.45 \mathrm{~m}$ between rows and 14 to 15 seeds per meter.

In the experiment in 2005 , the following treatments were evaluated: without $\mathrm{N}$ and without inoculation (control); $\mathrm{N}$ treatment with $200 \mathrm{~kg} \mathrm{ha}^{-1} \mathrm{~N}$ in the form of urea (50\% applied at planting and $50 \%$ applied 35 days after plant emergence) ( $\mathrm{N}$ treatment); inoculation with a commercial product containing the Bradyrhizobium japonicum strains SEMIA 5079 (=CPAC 15) and SEMIA 5080 (=CPAC 7); seed treatment with a carbendazim + thiram-based fungicide and inoculation with a commercial product containing the $B$. japonicum strains (Fungicide $+B$. japonicum); inoculation with a commercial product containing the B. elkanii strains SEMIA 587 and SEMIA $5019(=29 \mathrm{~W})$, and seed treatment with a carbendazim + thiram-based fungicide and inoculation with a commercial product containing the B. elkanii strains (Fungicide $+B$. elkanii). The commercial inoculant with the strains SEMIA 5079 and SEMIA 5080 of $B$. japonicum consisted of a peat-based product, while the product containing the $B$. elkanii strains SEMIA 587 and SEMIA 5019 was in liquid form.
Immediately before planting, the soybean seeds of all treatments were moistened with around $3 \mathrm{~mL} \mathrm{~kg}-1$ of $10 \%$ sugar solution and homogenized. Then the product was applied to the seed treatments with fungicides at a concentration of $300 \mathrm{mg} \mathrm{kg}^{-1}$ of active ingredient (a.i.) carbendazim plus $700 \mathrm{mg} \mathrm{kg}^{-1}$ of active ingredient (a.i.) thiram. Thereafter, the seeds were inoculated with the Bradyrhizobium strains at a concentration of approximately 1.2 million cells per seed.

In the second experiment, the B. elkanii strains SEMIA 587 and SEMIA 5019 and B. japonicum strains SEMIA 5079 and SEMIA 5080 and the fungicides containing carbendazim + thiram and also carboxin + thiram were evaluated. The treatments consisted of the individual inoculation with the strains of the soybean seeds, fungicide-treated or not, as well as a $\mathrm{N}$ treatment and a control as described for the first experiment. All strains were prepared experimentally on a peat-based substrate, using a dose of 1.2 million cells per seed. The soybean seeds were treated and inoculated in a similar way as in the previous experiment, with fungicide concentrations on the seeds of $300 \mathrm{mg} \mathrm{kg}^{-1}$ of active ingredient (a.i.) carbendazim plus $700 \mathrm{mg} \mathrm{kg}^{-1}$ of a.i. thiram, and $600 \mathrm{mg} \mathrm{kg}^{-1}$ of seeds of the active ingredient (a.i.) carboxin plus $600 \mathrm{mg} \mathrm{kg}^{-1}$ of i.a. thiram.

The nodules number and dry weight, dry matter and total-N of the shoots were evaluated 35 days after plant emergence; and at harvest, the grain yield (moisture corrected to $13 \%$ ) and $\mathrm{N}$ accumulated in the grain were evaluated.

The data obtained was submitted to variance analysis by the F test, and the means compared by the Tukey test at a level of $5 \%$. Data of the experiment of 2005 were analyzed with a single factor, and those of 2006 considering a 4 x 3 factorial scheme, with four strains of Bradyrhizobium and three fungicide treatments (without fungicide, carbendazim + thiram and carboxin + thiram).

\section{RESULTS}

In 2005, it was observed that the soybean seed treatment with the carbendazim+thiram-based fungicide interfered directly with plant nodulation. In general, there was a significant reduction, more than $50 \%$, in the nodules number an dry weight the treatment with B. elkanii strain inoculation and also a reduction of more than $50 \%$ in the nodule number of the plants inoculated with B. japonicum (Table 1).

Greater plant dry matter production and total-N in the shoots in the $\mathrm{N}$ treatment, and less production in the control was observed (Table 1). Among the inoculated treatments, significant differences were not observed through the presence of the fungicide, although the plant dry matter of the treatments with the treated seeds was around $25 \%$ less for the strains 
Table 1. Effect of seed treatment with the carbendazim + thiram-based fungicide on soybean nodulation, plant dry matter, and grain yield of plants inoculated with Bradyrhizobium japonicum (strains SEMIA 5079 and SEMIA 5080) and B. elkanii (SEMIA 587 and SEMIA 5019) in a field experiment conducted in the Cerrado region of Roraima, in 2005

\begin{tabular}{|c|c|c|c|c|c|c|}
\hline Treatment & $\begin{array}{l}\text { Nodule } \\
\text { number }\end{array}$ & $\begin{array}{l}\text { Nodule dry } \\
\text { weight }\end{array}$ & $\begin{array}{l}\text { Plant dry } \\
\text { matter }\end{array}$ & $\begin{array}{l}\text { Total-N in } \\
\text { the plant }\end{array}$ & $\begin{array}{r}\text { Grain } \\
\text { yield }\end{array}$ & $\begin{array}{l}\mathrm{N} \text { in the } \\
\text { grain }\end{array}$ \\
\hline & & $\mathrm{mg} / \mathrm{plant}$ & g/plant & $\mathrm{mg} /$ plant & $\mathrm{kg} \mathrm{ha}^{-1}$ & - \\
\hline Control & $1,8 \mathrm{c}$ & $44 \mathrm{~b}$ & $3,6 \mathrm{~b}$ & $103,9 \mathrm{~b}$ & $2.413 \mathrm{~b}$ & $159 \mathrm{~b}$ \\
\hline Nitrogen & $1,1 \mathrm{c}$ & $15 \mathrm{~b}$ & $7,3 \mathrm{a}$ & $205,1 \mathrm{a}$ & $4.142 \mathrm{a}$ & $271 \mathrm{a}$ \\
\hline B. elkanii & $8,9 \mathrm{ab}$ & $180 \mathrm{a}$ & $4,3 \mathrm{~b}$ & $136,9 \mathrm{ab}$ & $3.965 \mathrm{a}$ & $260 \mathrm{a}$ \\
\hline Fungicide $+B$. elkanii & $3,1 \mathrm{c}$ & $55 \mathrm{~b}$ & $4,0 \mathrm{~b}$ & $140,3 \mathrm{ab}$ & $3.406 \mathrm{ab}$ & $220 \mathrm{ab}$ \\
\hline B. japonicum & $16,5 \mathrm{a}$ & $264 \mathrm{a}$ & $5,6 \mathrm{ab}$ & 199,6 a & $4.030 \mathrm{a}$ & $264 \mathrm{a}$ \\
\hline Fungicide $+B$. japonicum & $8,1 \mathrm{~b}$ & $164 \mathrm{a}$ & $4,0 \mathrm{~b}$ & $127,5 \mathrm{ab}$ & $3.954 \mathrm{a}$ & $264 \mathrm{a}$ \\
\hline $\mathrm{VC}(\%)$ & 33,4 & 25,0 & 27,6 & 32,2 & 13,7 & 15,2 \\
\hline
\end{tabular}

Means followed by the same letters in the columns were not statistically different by the Tukey test at a level of $5 \%$.

of $B$.japonicum and $10 \%$ for B. elkanii. In addition, a difference in absolute terms of almost $40 \%$ in total$\mathrm{N}$ in the shoots of the plants was observed between the treatment only inoculated with $B$. japonicum (which had a value greater than that of the control) and the treatment inoculated with this strain and treated with fungicide, which presented a value equal to that of the control (Table 1).

In terms of yield and $\mathrm{N}$ accumulated in the grains, it was observed that the fungicide seed treatment did not result in a negative effect in the plants inoculated with B. japonicum, whereas for the treatment fungicide $+B$. elkanii there was a reduction of around $15 \%$, for both yield and accumulated $\mathrm{N}$ in the grain (Table 1 ). This reduction in productivity and $\mathrm{N}$ accumulation in the grain resulted in values which were significantly equal for the treatments fungicide + B. elkanii and control, whereas, in the absence of fungicide, the values of the B. elkanii treatment were equal to those of the $\mathrm{N}$ treatment and to that of inoculation with $B$. japonicum, and greater than of the control (Table 1).

In the experiment conducted in 2006, it was observed that the seed treatment with carbendazim + thiram or carboxin + thiram did not significantly interfere the number of nodules (data not shown) and nodule dry weight of the treatments with the $B$. japonicum strains SEMIA 5079 and SEMIA 5080, although in absolute terms there was less nodulation in the plants when the seeds were fungicide-treated (Figure 1a). On the other hand, for the B. elkanii strains SEMIA 5019 and SEMIA 587, there was a reduction in nodulation caused by both fungicide seed treatments, reaching more than $50 \%$ in the case of carbendazim + thiram (Figure 1a).

In the plant shoots, as likewise observed in the experiment of 2005, significant differences were not seen among the treatments with and without fungicides; the only significant difference of the inoculated and $\mathrm{N}$ treatments was observed in relation to the control (data not shown).

At harvest, no effect of the fungicides was observed in the treatments inoculated with the B. japonicum strains and B. elkanii SEMIA 5019, although there was a reduction in grain yield of around $15 \%$ in the treatment with the latter strain when the seeds were treated with carbendazim + thiram (Figure 1b,c). On the other hand, the seed treatment of carbendazim + thiram-based fungicide caused reduction in the yield and in the $\mathrm{N}$ accumulation in the grains inoculated with the strain SEMIA 587, this reduction being greater than $22 \%$, around $700 \mathrm{~kg} \mathrm{ha}^{-1}$.

\section{DISCUSSION}

Due to the low content of organic material in the soil and consequent low N content, soybean cultivation in Roraima as well as in various other areas of Brazil depends largely on the process of BNF. If this process does not occur to a sufficient extent, crop development is limited (Zilli et al., 2008); this requires that management practices of soil, seeds or crop with potential risks to BNF must be carefully evaluated prior to application.

The low phytosanitary quality of a large part of the seeds used in Brazil, together with the risks of plant density reduction in the fields, has created a situation in which, since 1992, fungicide soybean seed treatment has been recommended. Fungicides based on the active ingredients carboxin, carbendazim and thiram, in spite of being considered efficient seed protectors (Revellin et al., 1993; Goulart et al., 2000) and less toxic to the inoculating strains used in Brazil (Campo \& Hungria, 2000), are potential nodulation 

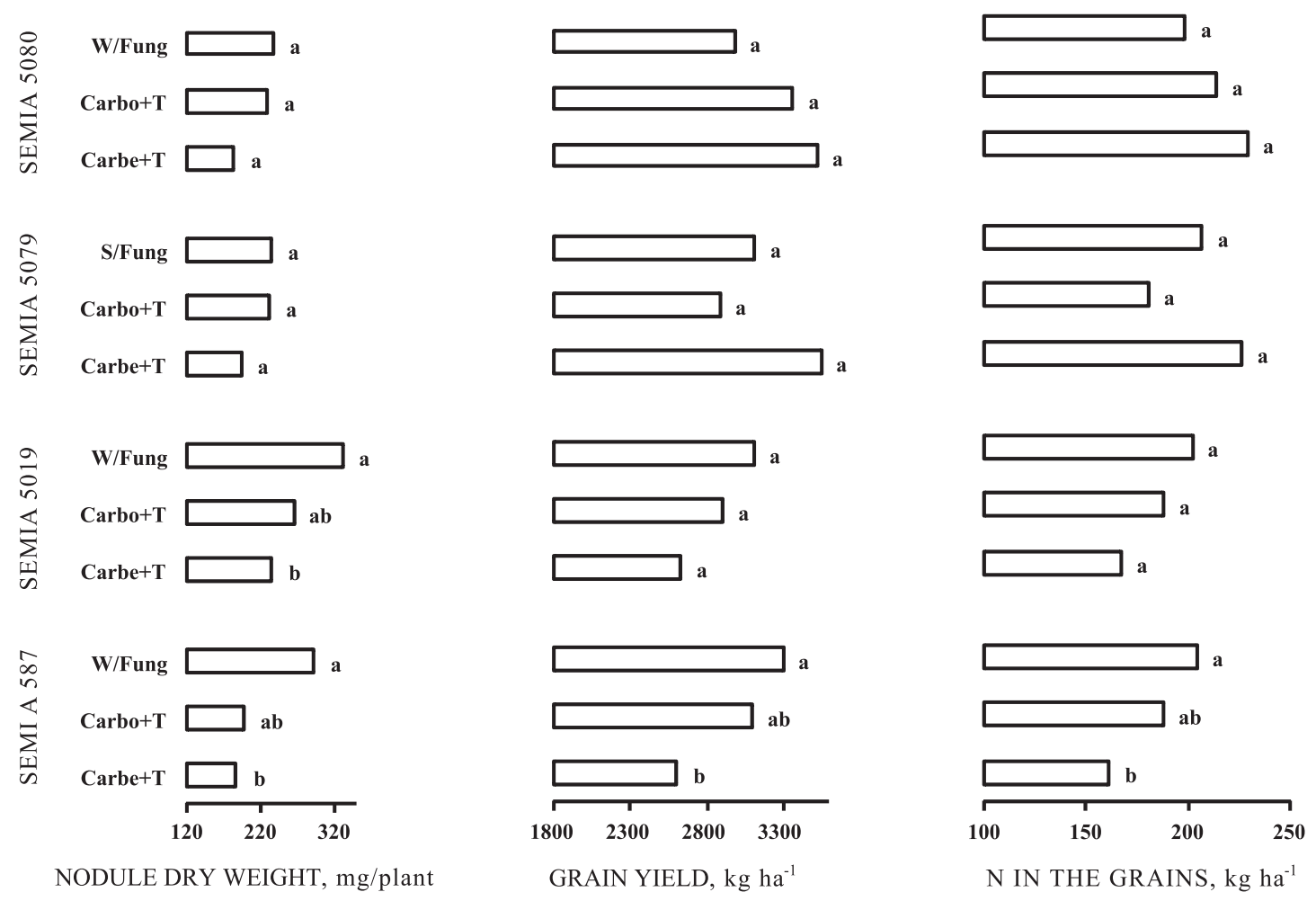

Figure 1. Effect of seed treatment with carbendazim+thiram and carboxin+thiram-based fungicides on nodule dry weight, grain yield and $\mathrm{N}$ accumulation in soybean grain inoculated with Bradyrhizobium strains in a field experiment in the Cerrado of Roraima in 2006. W/Fung - Without fungicide; Carbo+T carboxin+thiram; Carbe+T - carbendazim+thiram. *Means followed by the same letter, for the same strain and variable, did not differ from each other by the Tukey test at a level of $5 \%$.

inhibitors and, consequently, harmful to soybean plant development (Hashem et al., 1997; Andrés et al., 1998).

In this study, we sought to evaluate the possible effects of the fungicide soybean seed treatment under field conditions which is possible to happen in commercial tillages. In the experiment in 2005 , planted on soil very poor in organic matter and practically without soybean-nodulating bacteria, it was observed that the carbendazim + thiram-based fungicide significanty reduced nodulation - especially the number of nodules - of the soybean plants with both inoculants containing B. japonicum or B. elkanii (Table 1). On the other hand, in 2006, there was a reduction in nodulation in all treatments with carbendazim+thiram or carboxin + thiram-based fungicides. Significant effects were observed for the B. elkanii strains when the seeds were treated with carbendazim + thiram (Figure 1).

These results indicate that, although both carbendazim+thiram and carboxin+thiram-based fungicides reduced soybean nodulation, more severe effects occurred with the combination of carbendazim + thiram and B. elkanii. In this case, the performance differed among the Bradyrhizobium species in the presence of this fungicide. The results obtained in
2006 also confirmed that the effects regarding the commercial inoculant with B. elkanii, in 2005 , were a result of the bacterial sensitivity to the carbendazim + thiram-based fungicide and not due to the fact that a product in a liquid form had been used, since there is an indication of greater bacterial sensitivity to the fungicides in case of liquid application (Hungria et al., 2007).

Some experiments performed in soybean-producing regions of Brazil by Campo \& Hungria (2000) showed little effect of the carboxin + thiram and carbendazim + thiram fungicides on soybean nodulation. Nevertheless, the study of these authors showed, in an evaluation conducted in the State of Paraná, a significant reduction of plant nodulation, of up to 39 and $70 \%$ for the carboxin + thiram and carbendazim + thiram-based fungicides, respectively, when inoculation was performed with the pair of strains of B. elkanii (Campo \& Hungria, 2000). In contrast, when inoculation was undertaken with the pair of strains of $B$. japonicum, soybean nodulation was practically not reduced (Campo \& Hungria, 2000).

In fact, compatibility between the fungicide seed treatment and inoculation with Bradyrhizobium strains appears to be directly related to the bacterial 
tolerance to the product. Although not very expressive effects of the fungicide thiram on $B$. japonicum have been reported (Revellin et al., 1993), direct effects of this same product on the same bacteria species were also described elsewhere (Andrés et al., 1998). Andrés et al. (1998) mentioned a negative effect of the fungicide thiram on $B$. japonicum, both under laboratory and in field conditions, causing a reduction in the number of nodules the soybean plants, especially those located at the root crown, with this effect being prolonged until plants flowering. Bueno et al. (2003) also observed negative effects of various fungicides on the survival of the B. elkanii strain SEMIA 5019 and B. japonicum SEMIA 5079. These authors also cite that the fungicides carboxin, carbendazim and thiram reduced bacterial survival in vitro by around $14 \%$, for both SEMIA 5019 and SEMIA 5079.

Agricultural chemicals may have different effects on rhizobium (Rennie \& Dubetz, 1984). The activity of the contact fungicide thiram has been shown to be directly related to the death of rhizobium cells, reducing the inoculant viability; in addition, the fungicide acts on the plant root, altering the exudate composition and, consequently, acts on the molecular signals to the bacteria and, moreover, alters the bacterial morphology and physiology (Andrés et al., 1998; Dunfield et al., 2000). For the fungicides carboxin and carbendazim, there are indications of action on the protein structure since their modes of action on fungi are the electron transport chain and inhibition of tubulin polymerization, respectively (Tucker \& Lillich, 1974; Davidse, 1986).

It was observed that a reduction in plant nodulation caused by the fungicide seed treatment did not result in a significant reduction in plant dry matter and $\mathrm{N}$ accumulation, although this reduction was up to $25 \%$ for dry matter and more than $40 \%$ for total $\mathrm{N}$ in the first experiment (Table 1). This probably occurred because until 35 days after plant emergence, when evaluation was made, the plant demand for $\mathrm{N}$ was still small and this need would be supplied by the nodules formed and also by the soil $\mathrm{N}$.

At harvest, on the contrary, it was observed that the nodulation reduction due to the fungicide seed treatment resulted in a grain yield reduction in the inoculation treatment with $B$. elkanii (Table 1 , Figure 1b). In 2005, the seed fungicide treatment with carbendazim + thiram resulted in a reduction of $15 \%$ of the grain yield, e.g., a loss of about $560 \mathrm{~kg} \mathrm{ha}^{-1}$ compared to the treatment that was inoculated only, significantly equal to the control. On the other hand, in 2006, it was possible to see that there was no significant effect of any of the fungicides on the yield of B. japonicum-inoculated soybeans and, despite a reduction of around $15 \%$ in grain yield in the treatment inoculated with the strain SEMIA 5019, this effect was not significant. For the strain SEMIA 587, however, the carbendazim + thiram-based fungicide led to a reduction in grain yield of over $20 \%$, which represents more than $700 \mathrm{~kg} \mathrm{ha}^{-1}$ soybean grain, apart from a reduction in $\mathrm{N}$ accumulation (Figure 1b,c).

A reduction in the soybean grain yield as a result of fungicide seed treatment can increase the risk of crop failure, a condition that is likely to occur. It is worth highlighting that, currently, authorization is being granted for the use of Bradyrhizobium strains in commercial inoculants both individually as well as in pairs (Campo \& Hungria, 2007), which increases the risks for nodulation as a result of fungicide seed treatment.

\section{CONCLUSION}

Soybean seed treatment with a carbendazim + thiram-based fungicide is incompatible with soybean seed inoculation with the Bradyrhizobium elkanii strain SEMIA 587, resulting in drastic reductions in plant nodulation and grain yield.

\section{LITERATURE CITED}

ANDRÉS J.A.; CORREA, N.S. \& ROSAS, S.B. Survival and symbiotic properties of Bradyrhizobium japonicum in the presence of thiram: Isolation of fungicide resistant strains. Biol. Fertil. Soils, 26:141-145, 1998.

BUENO, C.J.; MEYER, M.C. \& SOUZA, N.L. Efeito de fungicidas na sobrevivência de Bradyrhizobium japonicum (SEMIA 5019 e SEMIA 5079) e na nodulação da soja. Acta Sci. Agron., 25:231-235, 2003.

CAMPO, R.J. \& HUNGRIA, M. Compatibilidade de uso de inoculantes e fungicidas no tratamento de sementes de soja. Londrina, Embrapa Soja, 2000. 32p. (Circular Técnica, 26)

CAMPO, R.J. \& HUNGRIA, M. Protocolo para análise da qualidade e da eficiência agronômica de inoculantes, estirpes e outras tecnologias relacionadas ao processo de fixação biológica do nitrogênio em leguminosas. In: REUNIÃO DA REDE DE LABORATÓRIOS PARA RECOMENDAÇÃO, PADRONIZAÇÃO E DIFUSÃO DE TECNOLOGIAS DE INOCULANTES DE INTERESSE AGRÍCOLA, 13., Londrina, 2006. Anais. Londrina, Embrapa Soja, 2007. p.89-123 (Documentos, 290)

COMPANHIA NACIONAL DE ABASTECIMENTO - CONAB. Indicadores da Agropecuária. Disponível em: <http:// www.conab.gov.br.> Acesso em: 11 ago. 2008.

DAVIDSE, L.C. Benzimidazole fungicides: Mechanism of action and biological impact. Ann. Rev. Phytopathol., 24:43-65, 1986. 
DUNFIELD, K.; SICILIANO, S.D. \& GERMIDA, J.J. The fungicides thiram and captan affect the phenotypic characteristics of Rhizobium leguminosarum strain $\mathrm{C} 1$ as determined by FAME and Biolog analyses. Biol. Fertil. Soils, 31:303-309, 2000.

EMBRAPA RORAIMA. Cultivo da soja no Cerrado de Roraima. Boa Vista, 2007. 84p. (Sistema de Produção, 1)

EMPRESA BRASILEIRA DE PESQUISA AGROPECUÁRIA EMBRAPA. Tecnologias de produção de soja - região central do Brasil. Londrina, Embrapa Soja; Embrapa Cerrados; Embrapa Agropecuária Oeste, 2008. 280p. (Sistemas de Produção, 12).

GOULART, AC.P.; ANDRADE, P.J.M. \& BORGES, E. Controle de patógenos em sementes de soja pelo tratamento com fungicidas e efeitos na emergência e no rendimento de grãos. Summa Phytopatol., 26:341-346, 2000.

GRAHAM, P.H. Ecology of root-nodule bacteria of legumes. In: DILWORTH, M.; JAMES, E.K.; SPRENT, J.I. \& NEWTON, W.E., eds. Nitrogen-fixing leguminous symbioses. Dordrecht, Springer, 2008. p.23-58.

HASHEM, F.M.; SALEH, S.A.; van BERKUM, P. \& VOLL, M. Survival of Bradyrhizobium sp. (Arachis) on fungicidetreated peanut seed in relationship to plant growth and yield. World J. Microbiol. Biotechnol., 13:335-340, 1997.
HUNGRIA, M.; CAMPO, R.J. \& MENDES, I.C. A importância do processo de fixação biológica de nitrogênio para a cultura da soja: Componente essencial para a competitividade do produto brasileiro. Londrina, Embrapa Soja, 2007. 80p. (Documentos, 283)

HUNGRIA, M. \& VARGAS, M.A.T. Environmental factors affecting $\mathrm{N}_{2}$ fixation in grain legumes in the tropics, with an emphasis on Brazil. Field Crops Res., 65:151-164, 2000.

RENNIE R.J. \& DUBETZ S. Effects of fungicides and herbicides on nodulation and $\mathrm{N}_{2}$ fixation in soybean fields lacking indigenous Rhizobium japonicum. Agron. J., 76:451-454, 1984.

REVELLIN, C.; LETERME, P. \& CATROUX, G. Effect of some fungicide seed treatments on the survival of Bradyrhizobium japonicum and on the nodulation and yield of soybean [Glycine max. (L) Merr.]. Biol. Fertil. Soils, 6:211-214, 1993.

TUCKER, A. \& LILLICH, T. Effect of the systemic fungicide carboxin on electron transport function in membranes of Micrococcus denitrificans. Ant. Ag. Chemoth., 6:572-578, 1974.

ZILLI, J.E.; MARSON, L.C.; MARSON, B.F.; CAMPO, R.J. \& HUNGRIA, M. Inoculação de Bradyrhizobium em soja por pulverização em cobertura. Pesq. Agropec. Bras., 43:541-544, 2008. 
